\title{
The Emerging IS Global Profession: Accreditation - The Quality Assurance Dimension
}

\author{
John Gorgone \\ Bentley College, Waltham, MA, USA \\ igorgone@Inmta.bentley.edu \\ Vijay Kanabar \\ Boston University, Boston, MA, USA \\ kanabar@bu.edu
}

\begin{abstract}
As the global economy has expanded, the demand for quality information systems (IS) people increased globally. Ascertaining the quality of education in IS programs at colleges located within and outside the boundaries of the USA has become increasingly important to employers, students and the public. Accreditation is the quality assurance dimension of IS. IS accreditation is a reality in the USA and "Substantial Equivalency" status is available to computing programs outside the United States now that CSAB has joined ABET. What is the status of IS accreditation? What is "Substantial Equivalency"? How can "Substantial Equivalency" be available to programs outside the USA? What constitutes an accredited program? Who benefits from accreditation? What are the criteria for accrediting information systems programs? This paper addresses these and other accreditation issues and questions.
\end{abstract}

\section{Introduction}

With the expanding global economy, the demand for a mobile, quality information systems (IS) workforce increased. Ascertaining education quality of IS programs at colleges and universities located within and outside the boundaries of the USA has become increasingly important to employers, students, parents, the public and the government. Accreditation is the quality assurance dimension of information systems. Information Systems accreditation is a reality in the United States of America and "Substantial Equivalency" status is available to IS programs outside the United States. What is the purpose and status of IS accreditation? Who benefits from accreditation? What constitutes an accredited program? What is "Substantial Equivalency"? How can "Substantial Equivalency" be available to programs outside the USA? What are the criteria for accrediting information systems programs? The purpose of this paper is to address these issues and other accreditation questions.

\section{Background}

Computer Science (CS) accreditation began in 1986 in the USA. There are currently 166 CS accredited programs at 158 institutions in USA (www.csab.org). Faculty and qualified industry visitors review programs on a continuing basis. The entire process takes nearly two years to complete. Interest in accrediting IS programs began in 1987. However, critical support did not occur until the late 1990's with the development of national IS curricula models and National Science Foundation (NSF) support.

A good basis for the establishment of IS criteria for accreditation became available with the development

Material published as part of these proceedings, either on-line or in print, is copyrighted by Informing Science. Permission to make digital or paper copy of part or all of these works for personal or classroom use is granted without fee provided that the copies are not made or distributed for profit or commercial advantage AND

that copies 1) bear this notice in full and 2) give the full citation on the first page. It is permissible to abstract these works so long as credit is given. To copy in all other cases or to republish or to post on a server or to redistribute to lists requires specific permission from the publisher at Publisher@InformingScience.org of a national IS curriculum model in the late 1990's. The major development and dissemination of IS'97, Model Curriculum and Guidelines for Undergraduate Degree Programs in Information Systems (Davis 1997), and the adoption or adaptation of this curriculum is a major contribution to the curricular portion of IS accreditation criteria. 
The Emerging IS Global Profession

Supported by a National Science Foundation grant, the project had representatives appointed from the leading computing societies in the US, ACM, Association for Information Systems (AIS), Association for Information Technology Professionals (AITP), IEEE Computer Society (IEEE-CS) and the Computing Sciences Accreditation Board (CSAB). Using the basic form and format developed by the Computer Science Accreditation Commission for accrediting Computer Science programs (www.csab.org) as a pattern, the Criteria for Accreditation of Information Systems Programs were developed. IS'97 referenced above provided the basis for the Curriculum portion of the Criteria. The Draft Information Systems Accreditation Criteria were discussed at numerous computer conferences, including ACM's Computer Science Education, (SIGCSE), Frontiers in Education, AIS's Americas Conference in Information Systems (AMCIS), AITP's Information Systems Education Conference (ISECON), International Academy for Information Management (IAIM) and International Conference in Information Systems (ICIS). Comments from these conference presentations were considered and the Draft Criteria were revised. Drawing the greatest interest was the IS curriculum area resulting in a web survey, conducted over the Internet, allowing public review of the curriculum. Over 300 people responded to the web survey. The survey was analyzed and the Draft Criteria were revised to develop into the "Criteria for Accreditation of Information Systems Programs."

\section{Status of IS Accreditation}

After several years of public review and feedback, the IS Criteria received CSAB approval in July 2000 and final approval from the ABET Board of Directors in November 2001. The criteria for accreditation and other documents can be found at http://www.abet.org/criteria.html. The IS self-study document has been prepared and IS program evaluators have been trained (To become a program evaluator see http://www.csab.org/). The 2001-2002 Program Review Cycle is in progress. One IS program was selected for review, the self-study completed and the campus program review was conducted in Fall 2001. In July 2002, accreditation action on the visit will occur and the institution will be informed of the action in August 2002. The next accreditation begins 2002-2003, with an institution submitting a request in January 2002, for program review in Fall 2002, and submits a completed self-study by June 2002.

\section{Purpose of Accreditation}

The main purpose of accreditation is assuring quality. It is certifying quality to students and the public. It is a sign that the program meets at least minimal standards for its faculty, curriculum, student services, libraries and fiscal stability. It is a way to engender employer confidence in hiring graduates from the program. It identifies programs for employers to provide tuition support for employees seeking education. It aids in easing transfer of courses among colleges and universities.

\section{Who Benefits from Accreditation?}

Many benefit from accreditation, including students, parents, employers, the public, the institution, the department and the program itself. Students' benefit by being assured that the knowledge being transmitted is necessary to prepare them to ably function as a professional in the information systems field. Parents have increased assurance of an educational investment and that the institution's accredited computing program will effectively prepare their adult child to enter professional practice or for graduate education.

Employers value accreditation because students graduating from an accredited program have attained an assured level of competence. This provides employers, with a degree of confidence, a workforce that has acquired a certain level of ability in the IS field. CSAB and ABET encourages employers to participate in the accreditation process, specifically by commenting on the Criteria, proposing and commenting on changes to the Criteria, and serving as Program Evaluators and Team Chairs for site visits to evaluate programs. 
The public is a stakeholder in accreditation, because as business, industry, government and individuals rely more and on information technology driven systems and the computer software that runs them, it is vital that minimum standards of preparation of IS workers be ascertained. It is necessary that the technology systems upon which the public relies be designed, developed and maintained by competent professionals. Accreditation is one way to assure, at least minimum preparation of people entering the IS workforce. As more information technology systems impact the life, health and safety of individuals globally, having competent information systems personnel is essential.

Accreditation benefits the institution, the department and the program being accredited. The self-study is in and of itself of benefit to the IS program. The reputation of the institution is enhanced when the IS program is recognized as having met the standards of accreditation. The department benefits by having an accredited IS program when it recruits students and as it works to hire and retain IS faculty. IS Program accreditation assists in quality assurance.

\section{What Constitutes an Accredited Program?}

An accredited program is one that has been reviewed by qualified and trained visitors and meets the Criteria established and approved by the Computing Accreditation Commission (CAC) of ABET. Only programs that are in institutions that have regional accreditation can be considered. This means that the evaluators visiting the institution are assured that the institution has in place the necessary infrastructure to offer programs leading to the degrees they offer, particularly on the undergraduate (baccalaureate) level. Accreditation is voluntary and an institution wishing to be accredited must request an accreditation evaluation.

\section{Time-Line for Accreditation of IS Programs}

A Request for Evaluation must be submitted to ABET by January 31 preceding the academic year in which the program desires a campus visit (http://www.abet.org/policies.html). The program must submit a self-study by July 1 and host an on-site visit in the September - November time frame. The institution will receive a Preliminary Statement of the Findings in March and the institution has 30 days to reply. The CAC Commission will vote on the accreditation action in July and the institution will be informed of the action in August. Thus the process takes more than 18 months.

\section{The Self-study}

The self-study is available at http://www.abet.org/info_prgs_cac.html and requires considerable information about the program, the faculty, the students and the environment in which the program is administered. It should be reviewed and started as early as possible to provide time for the institution to collect the necessary data. The program must have objectives. The institution must show how they meet these program objectives.

\section{Display Materials}

One of the important parts of the campus visit is looking at the displays. The displays need to include syllabi, texts, and graded, sample work fo every course in the is curriculum. The graded work needs to include samples of excellent, good and por of the preparation for the visit.

\section{Global Accreditation Perspectives}

Accreditation can be either a voluntary act or a requirement. In the United States program accreditation is usually a voluntary act by an education institution. Some States in the USA make accreditation a requirement in order to receive State funding. In computing, ABET reviews and accredits all programs in 
The Emerging IS Global Profession

computing in the USA. However, accreditation is not limited to institutions in the United States. There are other accreditation bodies in other countries that accredit programs. But, it is not the purpose of this paper to address this issue. We leave that for a future study. Next, we present ABET's role in recognizing programs internationally - the "Substantial Equivalency" standing.

\section{“Substantial Equivalency” Status for Global Assurance}

Upon the request by institutions, the ABET Accreditation Board conducts reviews of programs located outside the United States. These assessments follow similar policies and procedures used for the accreditation process in the US. ABET representatives act on a consultancy basis and evaluate or review the program. The assessment may lead to the "Substantial Equivalency" status of the reviewed program with accredited programs in the United States. " 'Substantial equivalency' means comparable in program content and educational experience, but such programs may not be absolutely identical in format or method of delivery." (http://www.abet.org/sub_equ_eva.html) No accreditation action is taken and there is no presumption that a program is to be accredited as a result of such review. The process simply implies that there is confidence that the graduates of the program possess the competencies needed to begin an entrylevel professional practice. “ABET normally will not undertake a 'substantial equivalency' evaluation without written con urrence from the highest possible level of the requesting institution or government of the country." (http://Www.abet.org/sub_equ_eva.htmI)

\section{The Global "Substantial Equivalency" Process}

To start the process, an institution must request a review in writing to the Executive Director of ABET. More details about the process of "Substantial Equivalency" evaluations can be found at http://www.abet.org/sub_equ_eva.html.

\section{Global Online Learning: Importance of Accreditation and Quality}

The role of accreditation and quality assurance becomes a critical one when it involves institutions dealing globally with Online Learning. What is Online Learning? Basically, it is distance learning using various instructional media such as computers, modems and Internet, television and web cams. The number of students associated with online learning was 71,, 000 in 1998, but is expected to exceed 2.23 million in 2002 (Moore, 2001). While there are advantages with online learning, there are issues that need addressed-both from the institutions and students perspectives (which accreditation can hopefully resolve). For example, an institution might invest millions of dollars in distance education technology and development. This commitment of resources does not necessarily ensure global acceptance of online learning as an acceptable alternative learning method. Such an acceptance can only come from quality assurance via accreditation. Accreditation can mitigate investment risks for an institution via a stamp of approval and assure the stakeholders, faculty, students, the public and government, of the educational quality. Such an approval could imply that the online classrooms effectiveness is comparable to the traditional classroom. Such an assurance could be of great value to all constituencies.

\section{IS Accreditation Criteria}

In order to give you a brief overview of IS accreditation criteria, we present excerpts from the IS Criteria document (http://www.abet.org/criteria.html). The criteria are divided into seven major categories. Each of the eight categories contains an intent and a minimum set of standards to meet each intent. An Intent provides the underlying principles associated with a category. For a program to be accreditable it must meet the Intent statement of every category. Standards provide a detailed description of how an information systems program can minimally meet the statement of Intent. Alternative approaches to achieving the Intent of a category are acceptable, but the institution must demonstrate that its approach provides an educational experience of equivalent value. The eight categories and the Intent of each category are pre- 
sented.

\section{Category I. Objectives and Assessments}

Intent: The program has documented educational objectives that are consistent with the mission of the institution. The program has in place processes to regularly assess its progress against its objectives and uses the results of the assessments to identify program improvements and to modify the program's objectives.

\section{Category II. Students}

Intent: Students can complete the program in a reasonable amount of time. Students have ample opportunity to interact with their instructors and are offered timely guidance and advice about the program's requirements and their career alternatives. Students who graduate from the program meet all program requirements.

\section{Faculty}

Intent: Faculty members are current and active in the discipline and have the necessary technical breadth and depth to support a modern information systems program.

\section{Curriculum}

Intent: The curriculum combines professional requirements with general education requirements and electives to prepare students for a professional career in the information systems field, for further study in information systems, and for functioning in modern society. The professional requirements include coverage of basic and advanced topics in information systems as well as an emphasis on a supportive area. Curricula are consistent with widely recognized models and standards.

\section{Technology Infrastructure}

Intent: Computer resources are available, accessible, and adequately supported to enable students to complete their course work and to support faculty teaching needs and scholarly activity.

\section{Institutional Support and Financial Resources}

Intent: The institution's support for the program and the financial resources available to the program are sufficient to provide an environment in which the program can achieve its objectives. Support and resources are sufficient to provide assurance that an accredited program will retain its strength throughout the period of accreditation.

\section{Program Delivery}

Intent: There are enough faculty members to cover the curriculum reasonably and to allow an appropriate mix of teaching and scholarly activity.

\section{Institutional Facilities}

Intent: Institutional facilities including the library, other electronic information retrieval systems, computer networks, classrooms, and offices are adequate to support the objectives of the program.

\section{Summary and Conclusion}

This paper addressed accreditation as the quality assurance dimension of Information Systems as it emerges as a global profession. It also presented the status of IS accreditation, defined "Substantial 
The Emerging IS Global Profession

Equivalency," explained what constitutes an accredited program, discussed who benefits from accreditation, and provided excerpts of accreditation criteria for accrediting information systems programs.

Ascertaining the quality of education in IS programs globally is an important issue as the mobilization of IS workers continue. IS accreditation is a reality in the USA. In countries where computing accreditation is not established, "Substantial Equivalency" status is available now that CSAB has joined ABET. Information Systems programs need encouragement to seek accreditation in order to confront the quality assurance issue, enhance the profession and recognize the mobility and importance of the workforce.

\section{Acknowledgements}

This project was funded by the National Science Foundation grant NSF DUE 9812278.

\section{References}

ABET web site at http://www.abet.org

CSAB web site at http://www.csab.org

Davis, D.B., Gorgone, J., Couger, JD, Feinstein, D., \& Longenecker, H. (1997). Model Curriculum and Guidelines for Undergraduate Degree Programs in Information Systems. The DATA BASE for Advances in Information Systems, 29, 1-94.

Lidtke, D., Feinstein, D., \& Gorgone, J. (2001). Panel on Information Systems Accreditation, Proceedings of the International Academy for Information Mqnagement, USA, P3-95.

Gorgone, J., Feinstein. D., \& Lidtke, D. (2000). Accreditation Criteria for IS/IT Programs. Issues in Information Systems, I, $166-170$.

Moore, G., Winograd, K., \& Lange, D. (2001) You Can Teach Online, McGraw-Hill Boston.

\section{Biographies}

Dr. John T. Gorgone is a Professor of Computer Information Systems and recipient of the Richard H. Rubin Professorship. In 1999, he received the Educator of the Year Award "for Outstanding and Exceptional Service to the Field of Information Systems Education" from the Association for Information Technology Professionals. He has chaired national computer conferences and has played a major role in developing ACM/AIS/AITP national curricula models in information systems. Professor Gorgone has over 170 published and/or presented professional papers and has been frequently noted in biographical listings -- most recently in 2000 Outstanding Scientists of the 20th Century (2000). He published articles in MIS Quarterly, Information Strategy: The Executive's Journal, The Data Base for Advances in Information Systems, Information and Management, Computing Research News, and Washington Report. His research interests include wireless communications, computer networks, IT work force issues, computer science and information systems curricula and accreditation standards. He is currently examining the feasibility of accrediting computer information science/systems/technology programs in a study funded by the National Science Foundation. Dr. Gorgone has extensive experience as a management and information technology consultant to Fortune 500 companies, U.S. State boards of higher education and college presidents.

Vijay Kanabar is an Associate Professor of Computer Science at Boston University. He has a PhD in Information Systems (Manitoba). His research interests are IS curriculum development, project management, ecommerce and web technology, database systems and multi-tiered architectures. 